\title{
Chapter 7 \\ Curriculum Theory in Contestation? American Curriculum, European Didaktik, and Chinese Wisdom Traditions as Hybrid Platforms for Educational Leadership
}

\author{
Tero Autio
}

\begin{abstract}
In this chapter, I attempt to theorize and historize the current global education reform movement which the Finnish education policy analyst Pasi Sahlberg (Finnish lessons: What can the world learn from educational change in Finland. Teachers College Press, New York, 2011) has coined the GERM (Global Education Reform Movement), the "virus that is killing education." The key drivers of that global education movement adopted in Western countries with very few exceptions render the triad of accountability, standardization and privatization as a marker of the corporatization of educational provision. More specifically, I will analyze the intellectual history of neoliberal ideology, its complicit academic contributions in instrumental curriculum theory and educational psychology with its historical succession of theories from behaviourist psychology to cognitive and learning theories. In this sense, William Doll's (1993) recognition of the Tyler Rationale's (Basic principles of curriculum and instruction. Chicago University Press, Chicago, 1949) intellectual affinity to Descartes's Method as a core of modernization is not incidental. Descartes's curriculum theory overtly co-equalizes between knowledge and ethics, but actually subordinates ethics to instrumental science and knowledge. Descartes' s initiatives led to the modernist stratagem where ethics seeks its refuge in the self-referentiality of logocentric Reason and, by implication, seeks to legitimate the moral supremacy of instrumental mode of rationality in human activities: the good in terms of instrumentality is the moral interior of the logocentric reason; hence there is no proper reason to question the validity and legitimacy of instrumental rationality. Simultaneously and significantly, the logocentric subject provides the hidden place and source of colonialism and exploitation. Finally, this chapter considers non-Western perspectives on curriculum in China.
\end{abstract}

T. Autio $(\bowtie)$

University of Tallinn, Tallinn, Estonia

e-mail: tero.h.autio@gmail.com 


\section{Introduction}

The widely recognized crisis in education that has been nationally and internationally documented in many research findings (e.g. Apple 2006; Hargreaves et al. 2009; Pinar 2013, 2011; Sahlberg 2011; Terhart 2003; Autio 2014, 2006) is arguably a crisis in educational leadership as well. In this chapter I will make an effort to balance the managerial stress on educational leadership genre by incorporating elements from internationally vibrant field of curriculum theory studies drawing on two major schools of thought. Curriculum theory is arguably of great significance to registering intellectual coordinates of education policy adopted. Curriculum theory would also be instrumental in overcoming the genre of education policy writing often epitomized as chronicling without any noticeable account of theoretical and historical affiliations. Against David Berliner's claim, "education reform is the hardest science of all" (in Lather 2010, 93), the lack of elaborated intellectual coordinates of policies seems groundless indeed.

Another dimension ignored more often that not in scholarly reporting of education crises is world political affiliations of those reform oeuvres. The prime example of the intense link between changes in the world political arena and education reforms is the 1957 Sputnik shock in the US with significant detrimental consequences on education policies and curriculum practices. In order to position the current issues of educational leadership beyond managerial rearrangements, we need to provide a broader analysis of a history of the current crisis in education.

First, I make an effort to deploy European, Anglo-American or broadly Anglophone, and Asian/Chinese variants of curriculum theory, their differing intellectual affiliations and their possible implications in the respective education reform and leadership mindset. China has a longest known education history for thousands of years, but I start my brief excursion from Europe from where Modern Education in the sense we know education today was witnessing its birth particularly by Jean Jacques Rousseau: The beginning of modern education - if we follow the dominant historiographies and philosophies of education - can be precisely dated, (...) in the year of 1762, in the year of publication of Rousseau's Emile. ... There is an old and a new, and the line of demarcation is the publication of the educational novel Emile in 1762 (Tröhler 2011, 61-62).

Rousseau's groundbreaking impact precedes the political ideals of the French Revolution 1789: Liberty, Equality, and Solidarity ("Fraternity") as the guiding beacons for the modern nation state, ideals of modern citizenship and modern education. Already Rousseau's early reception - due to many factors not the least because of his polemics seeking traits of character - was quite problematic still ultimately indispensable: in Germany where his reception was most ambivalent, Karl Georg von Raumer, the author of the four-volume Geschichte der Pädagogik (1843-1847), after first demoting Rousseau as a simple critic of France, "'that civilization has gone to rot", in the conclusion he compares Rousseau to the one of the Seven 
Wonders of the World, the lighthouse of Alexandria, lighting the way for the French in politics and for the Germans in education" (In Tröhler 2011, 63-64, my italics).

In retrospect, Raumer's geographical division of Rousseau's reception in French notions of politics and German concepts of education appears illuminative and allegorical in our present context of education crises. The shared and critical core in both receptions is concepts of freedom and liberation in epistemic and psychological terms (liberation from ignorance and coping with "passions") and political liberation from societally produced inequalities. Rousseau emphasized the necessity to perceptively and constantly fight against the internal (passions) and external (societal) obstacles for freedom; he conceived of freedom as a desirable personal, social and civic virtue - and its lack as a vice, an index of weakness of character and subordination to institutions. "Freedom is found in no form of government; it is in the heart of the free man. He takes it with him everywhere. The wile man takes his servitude everywhere" (Rousseau, in Tröhler 2011, 36).

Rousseau's decisive impact on German concepts of education is reflected in the original ideas of Bildung that necessarily remained an unfinished project yet programmatic to this day.

The Bildung tradition is anything else but a coherent and unified school of thought. There are a myriad of internal debates, derivations and variants within the Bildung movement and it has also powerfully affected notions and practices of education outside Europe. I will choose, reconsider and reactivate some topics and issues that would, in my view, provide alternative intellectual resources and inform the ignored dialogue between educational leadership and curriculum theory amidst the worldwide crisis in education.

The first and inalienable still contested principle in Bildung theories with significant implications to all domains of education from education policy to teacher education is freedom. The principle of freedom was characterized in different aspects of modernity; in theological, political, philosophical-scientific, and educational redefinitions of respective realities. Modernism at large means to liberate, to get rid of theological, philosophical and scientific beliefs petrified as stable, unquestionable dogma in geographically distinctive realities postulated, initially and respectively, in ancient Jerusalem and Athens. The engine of modernity was a cognizance of possibility for dynamizing the assumedly stabile reality by introducing new concepts basically based on freedom, newly acclaimed liberties from traditional authorities. In theology, the principle of freedom embodied in an attempt to get free from the papal authority in the sixteenth-century movement for the reform of abuses in the Roman Church ending in the establishment of the Reformed and Protestant Churches. Theological discourses imply significant consequences to modern education, curriculum theories and practices, educational leadership as no exception. In fact, the two major paradigms of Western curriculum theory - Anglo-American Curriculum and North European Bildung - are reducible to secular embodiments of two variants of Protestantism - respectively Calvinism and Lutheranism - in their effort to discarding the papal authority appreciated as corrupt. In tandem with the 
huge impact on the birth of modern worldview by René Descartes (1596-1650), these two Protestant movements render the two distinctively different intellectual profiles for modern Western rationales of education.

The intellectual history of Bildung got a decisive impetus from Immanuel Kant (1724-1804). An anecdote of Kant's externally ordered life in Königsberg (the present Russian city of Kaliningrad) on the south eastern corner of the Baltic Sea anecdotally evidences the influence of Rousseau on the shape of German education. The story creates a stereotypical punctual picture of professor Kant who made his daily walk in the city with precision that inhabitants were able to check their clocks. The only exception from Kant's predictable routines took place - the story goes - when he started to read Emile and forgot the time.

The Rousseaun inspired concept of freedom featured prominently Kant's moral philosophy and reflected in Kant's own lectures on pedagogy (Kant 1991). Kant's moral philosophy had groundbreaking consequences not only in the domain of moral philosophy per se but also on theories of mind, subjectivity and education. The Kantian concept of freedom affected by Rousseau would be the first historically perceivable antecedent between the divide of Bildung and Anglophone psychologized Curriculum. The divide is predicated on methodological and educational implications of Kant's moral philosophy: is the human being capable of autonomous decisions or exclusively determined by natural forces?

Kant argued that conformity to the Categorical Imperative, the CI (a noninstrumental principle) and hence to moral requirements themselves, can nevertheless be shown to be essential to rational agency. This argument was based on his striking doctrine that a rational will must be regarded as autonomous, or free in the sense of being the author of the law that binds it. The fundamental principle of morality - the CI - is none other than the law of an autonomous will. Thus, at the heart of Kant's moral philosophy is a conception of reason whose reach in practical affairs goes well beyond that of a Humean 'slave' to the passions. Moreover, it is the presence of this self-governing reason in each person that Kant thought offered decisive grounds for viewing each as possessed of equal worth and deserving of equal respect. (http://plato.stanford.edu/entries/kant-moral/ Kant 1984).

Kant's perception of free will as a preconditon of morality is deeply predicated on the North European and particularly Scandinavian notions of education and curriculum: for instance, to position the teacher, ideally, as an autonomous and free professional as the center of an education system whose main mission is to advance the holistic development of her/his students: "scratch a good teacher and you will always find a moral purpose." The Moral in this broad sense is often misinterpreted and atrophied as moralistic but its historical core meaning is related to the holistic understanding of human condition where an individual with her/his developing capacity of personal judgment - as free moral agent - orchestrates the acquired content of education comprised in the curriculum (Autio 2014). More closely, in the Bildung concept, cognitive, aesthetic, and practical dimensions of curriculum are 
instrumental ones and what makes education educative is just moral judgment about the worthwhileness, value and relevance of studied and learned material. In Bildung inspired curriculum theories, cognitive, aesthetic and practical dimensions are related to instrumental rationality that focus on the pragmatic usability of acquired knowledge, skills and attitudes whereas the moral dimension of the Bildung curriculum represents the reflective modus of rationality that gives subjective meaning to the "content", the studied and learned in the sense what Max Weber called value rationality (Vernunft; Wertrationalität) beyond its direct pragmatic usability. Finally, the moral dimension of curriculum in the classical Bildung sense asks about conditions for possibilities and limits of instrumental rationality for meaningful, sustainable human existence (Klafki 1991, 31).

The disconnection of morality from intellectual agendas of education could be argued to have theoretically advocated the current crisis in education, curriculum and leadership. Without adopting a view on curriculum as "a complicated conversation" (Pinar) where contestation over goals, purposes and meanings necessarily are part and parcel of democratic and educational conversation, we suffice to witness the current simulation of education and educational leadership around managerialist "best practices", testing industry and test scores as goals and explicit business of education and education policy.

The eclipse of the comprehensive Vernunft rationality - embodied as a shortage of complicated conversation transcending means and methods - on the agenda of education, curriculum and educational leadership is an index of a larger historical phenomenon. Max Weber (1864-1920), in his classical but fragmentary studies on Western or "Occidental" rationalism (Weber 1978), made efforts to explain the peculiarly rationalized nature of "our European-American social and economic life," that is manifest specifically in the establishment of the capitalist economy and the modern state. Weber's treatment of the development of rationalization is pertinent and illuminative from educational viewpoint: how moral concerns give way to instrumental modes of rationality in curriculum theory and educational leadership. For Weber, rational action functions as two-way, reciprocal dynamics between single individuals and societal institutions; first, rational action by transcending individual interests advocates motivational anchoring of the individual in societal institutions and, second, posttraditional moral or psychological remakings of the self emerge as institutional embodiments. Instrumental rationality is deeply embedded in modern institutions; moral concerns are amenable to get reified as legal or other formal and regulative principles. An example would be the model of the Scandinavian welfare society where morality is instrumentally embedded in the mediating structures between self and society for the assumed and legally rationalized common good. The political ingenuity may not be related directly to solidarity - as it is often interpreted - but to sublimated and rationalized egoism, to moral and psychological remaking of the self by the state as a better deal to "me" (and indirectly to others as well) what would be the case without the mutual, instrumental social contract between egoistic "me" and society. 
Instrumental rationality stands for Weber as the ideal type of Western rationalism, as a yardstick against which other orientations of social action could be ordered and against which they could be assessed (Autio 2006, 114). "Ideal types" always guide education and curriculum thought. Western modernization is succinctly interpretable in terms of tight interrelatedness between instrumental rationality and knowledge subordinated to instrumental interests:

When we use the expression "rational" we suppose that there is a close relation rationality and knowledge. ... for rationality has less to do with the possession of knowledge than with how speaking and acting subjects acquire and use knowledge. (Habermas 1984, in Autio 2006, 114)

The methodical and pragmatic stress is characteristic for instrumental rationality, where knowledge is assessed by its assumed capacity for instrumental mastery of reality. Habermas (1984, 10; Autio 2006, 114) introduces the concept of cognitive-instrumental rationality that has, "through empiricism, deeply marked the self-understanding of the modern era". Instrumental rationality specified by Habermas leans on two basic premises. The first is the notion of truth conceived in empiricistic terms, and the second is the notion of effectiveness. This set of premises with its overall instrumental rationale render a major theme on educational agendas with minor still prominent variations (Dewey!) in the theme in the US since the turn of the twentieth century and in Europe more gradually since the end of WWII. The "icon" of modernist curriculum, the Tyler Rationale (Tyler 1949), would embody and deploy in an exemplary way the grand Western symbolic curriculum:

Empirical ("evidence-based"!) "truths" and pragmatic "effectiveness" stripped out of all metaphysical or moral considerations would form a kind of circular reasoning in curriculum planning, where educational goals are constantly revised in the light of "scientific findings" and "needs" of society, which, in turn, are to be tested against their effective applicability indicated as preferred behavior changes in students (Autio 2006, 114).

In such forms of knowledge, the answer to the basic curriculum question "what knowledge is of most worth" is obvious: instrumental knowledge - that still remains deeply problematic from sustainable education point of view:

Paradoxically, the greater the level of factual knowledge of the world the further the retreat of the possibility of discovering its meaning. Action based on scientistic knowledge tends to be instrumental, focusing on short-run calculators of self-interest rather than long-term commitment. (Crook et al. 1992)

There are countries that still are opposing the scientism of truth-effectiveness in education and its most recent, openly politicized form, neoliberalism, most notably Finland. More generally, while acknowledging some serious biases in the Bildung tradition (its gender-structured nature, elitism, idealistic aestheticism and apolitical propensity), some other vital elements of Bildung could still deserve resurrection to provide credible alternatives to narrow and biased scientist-empiricist concept of 
knowledge and curriculum. There are attempts to rephrase and reactivate comprehensive education discourse exemplified in international "complicated conversation" in US curriculum studies and Chinese education and curriculum reforms, but the international big picture of curriculum and educational leadership is the embodiment of presentist excesses of instrumentalism devoid of democratic dialogue and historical-theoretical reconsiderations.

\section{A Brief Intellectual History of Present Transnational Education and Curriculum Policy and Leadership Crisis}

I will engage closer with internal manifestations of instrumental rationality in education and their historical-theoretical conditionings. I will restrict my focus on some sets of those conditionings that would arguably play a complicit role in our present education and its leadership crisis. I will follow the European Protestant theological discourses and some Kantian-Herbartian educational ideas, their transatlantic travelling and their reception in the rapidly industrializing United States around the turn of twentieth century. That primary stage between the cross-continental academic studies of education, theological discourses and the economy would provide an allegory for the coming times in the twentieth and twenty-first century in Western education. I will start at the end by the characterization of the current crisis and then make efforts to make them more comprehensible by an appeal to those earlier intellectual developments.

As a beginning, I would provide a short diagnosis of the educational (policy) crisis of our times that has been named differently: in Andy Hargreaves et al. (2009) Bigger, Harder, Tighter, Flatter strategy, in William Pinar's (2006, 2011) several critiques of "The End of Public Education in The United States" to expose his worries about the deliberate destruction of public education. In Pinar's view

the end of education in America was indicated by the plundering of public budgets by private companies. And with the privatization of schooling teachers have devolved into bureaucrats, checking students' completion of online assignments. In universities, economists have replaced education professors as the experts in federally funded educational research. (http://www.ced.zju.edu.cn/english/redir.php?catalog_id=39270\&object_id=69658)

Diane Ravitch who worked for the President George W. Bush and initially introduced the triad accountability, standardization and privatization as the guidelines of neoliberal education and curriculum policy reforms changed completely her mind after the recognition of the detrimental effects of the Bush Regime's No Child Left Behind and President Obama's reform initiative Through Race to the Top (Ravitch 2010). The Finnish education policy analyst Pasi Sahlberg characterizes the current education and curriculum policy mainstream as the Global Education Reform Movement, "the GERM that is killing education" (Sahlberg 2011) and strictly contrasts it with the Finnish education reform strategy that will take an even further step 
away in the new 2016 Finnish National Curriculum Reform from the Anglophone driven accountability, standardization and privatization reforms.

\section{The Sputnik Shock and the "Educationalization of the Cold War" as a Precursor for the Current Neoliberal Education Policy}

The longstanding narrow Culture of Method (Autio 2014, 2006) in both education research and practical teacher education programs has often, paradoxically for methodological reasons (if we think of method as a way to comprehensive and truthful evidence), prevented from seeing education as affected by larger complex of political, historical, cultural and theoretical issues. The Cold War culminated in the Sputnik Shock 1957 when Russians seemed to win the first match in space race by sending the kerosene-driven Sputnik rocket on the earth-circulating orbit. The political consequences resulted in fundamental change in reform mindset in the U.S. education: “... the enemy was not only the Russians but also the progressive educational ideology that was dominant in the United States at that time, supported by philosophers of education and the powerful teachers' unions" (Tröhler 2013, 200, my emphasis). The establishment of the OECD in the aftermath of the Sputnik Crisis institutionalized the both efforts to "reform" (deform?) the then progressive U.S. education and combat the Soviet Union's assumed technological and educational superiority by the educationalization of the Cold War. Symptomatic of the educational paradigm that followed was the first founding meeting of the OECD that was occupied by the representatives of the military and economy with no education expert keynotes (Tröhler 2011, 205). The defensive political and economic agenda dictated new, radically narrowed guidelines for education and curriculum: mathematics, sciences, and foreign languages as the "core curriculum", almost identical to the PISA trilogy of today.

The founding event was a turning point when education policy and particularly assessment and evaluation as a natural part of pedagogic process and teachers' work are removed to external, quasi-authoritative sources of testing industry advocated and designed by educational psychologists. In academic terms, the Sputnik Shock prompted the shift from educational philosophy to psychology as an intellectual core of the curriculum and teacher education programs. The final impetus for assessment and testing as a core of education policy and educational leadership came some years later, in 1966, from the massive survey, "second largest social science survey in history", lead by the University of Chicago sociologist James S. Coleman: Equality of Educational Opportunity Study. What was striking and what made it "the most dangerous report in American education" (Moynihan, in Pinar 2006, 123) is that "After Coleman, ..., equal opportunity was to be measured by 'outputs,' among these (in Coleman's study) the test scores of 570,000 children. Only if students from differing groups (social background, race, color, religion, and national 
origin, my add.) scored roughly the same scores, Coleman insisted, could we conclude there was equal educational opportunity" (Pinar 2006, 124).

Central to those powerful standardizing efforts is the role of educational psychology, which meant a shift from pragmatic philosophy to schematic, radically simplified notions of human learning by behaviorism and cognitive theory:

The educationalization of the Cold War in the United States marked a transformation of the dominant reference discipline for education, for it switched from philosophy to psychology, more precisely from popular interpretation of Pragmatism to cognitive psychology, which was at its outset in the late 1950s - cognitive theory being the most important academic reference of PISA today, as the stakeholders admit themselves. (Tröhler 2013. 201)

The switch from philosophy to psychology also meant - paradoxically - the disappearance of the subject on the agenda of education for the abstract, reified and universal notions of "learning". The whole historical array of (educational) psychologies from behaviorism to cognitive theories to "Learning Sciences" is fundamentally a-psychological by nature without any substantive reference to human psyche as a distinctive, complex entity sui generis. Initially for behaviorism, consciousness was too complicated and messy phenomenon to be directly graspable and the study of consciousness was replaced by the observation of outer behavior with the methods already employed in natural sciences in accordance with the politics of positivist agendas: to see in order to control and predict.

The trend to a priori schematize human consciousness is closely related to the instrumentalism of modernization with the influential Cartesian emphasis on Method in the creation of new knowledge and the rise of natural sciences in the seventeenth century. One of the most pivotal figures in the history of education, Johann Friedrich Herbart (1776-1841), had ambivalent and contrasting alternatives for the notions of psychology (Blass 1978) with far-reaching implications for both European and Anglo-American developments of education and curriculum theory. Herbart, as the follower of Immanuel Kant (1724-1804) in Königsberg (today's Russian Kaliningrad), made efforts to combine freedom - necessary condition for Kant to design the moral sphere, free "judgmental reason" as the core of human rationality - with causal necessity. For Herbart, the intellectual "mission impossible" was to unite the moral end of education, the idea of inner freedom manifested ideally as knowledgeable and enlightened moral character, informed but not exclusively determined by external powers and authorities, with deterministic and exact ideals of scientific psychology developed in accordance with the methodology of the natural sciences (Autio 2006, 105).

The unbridgeable split remained to respectively live in two radically differing intellectual alternatives for Western curriculum theory: North European Bildung/ Didaktik and Anglo-American Curriculum. The European concept of curriculum initiated by Humboldt suggested that the cognitive, practical and aesthetic dimensions of curriculum are to be subordinated to the fourth dimension, the moral, (Klafki 1991), the decisive instance of human rationality and freedom (Vernunft) that would guarantee the educative and transformative nature of education beyond proceduralism. The practical and democratic implication would be that teachers and 
students alike are called to use their free judgmental faculties to richen the educative experience of all participants by subjectively scrutinizing the meaning(fullness) of the learned content and its context; in Pinar's current words: "curriculum as a complicated conversation" where "subjectivity is threaded through the curriculum" (Pinar 2013). Already Kant himself (Autio 2006, 102) warned in his pedagogic lectures - as if anticipating the present colonization and standardization of reason and educational experience by psychological, administrative and commercial instrumentalism:

Intelligence divorced from judgment produces nothing but foolishness. Understanding is the knowledge of the general. Judgment is the application of general to the particular. Reason is the power of understanding the connection between the general and the particular.

The moral, that is: the reflective, free faculty of human mind with its contextualized focus on "the primacy of the particular" (Pinar) is in strict contrast with the behaviorist tenet of inductive, non-subjective generalization of abstract "learning". Actually, this kind interpretation of the moral is one of the divisive intellectual factors between Bildung/Didaktik and the present of the neoliberal Anglo-American Curriculum and its global extension. The intellectual breakthrough in the US curriculum theory by Pinar and his colleagues (1995), the Reconceptualization, radically rephrased and opened new theoretical perspectives for curriculum thinking beyond procedural and abstract educational psychology. Simultaneously, like just the name of Pinar's et al. book, Understanding Curriculum, reveals, the Reconceptualization was intellectually affiliated with the Continental hermeneutic school of (educational) thought tentatively instigated by the German Movement around 1770-1830 but articulated more distinctively in the hermeneutic ("geisteswissenschaftliche") works of Friedrich Schleiermacher (1768-1834) and Wilhelm Dilthey (1833-1911). Dilthey's argument centered around the idea that in the natural sciences we seek to explain phenomena in terms of cause and effect; contrastively, in the human and social sciences, we seek to understand meanings in terms of relations between parts and a whole; "Die Natur erklären wir, das Seelenleben verstehen wir." (Dilthey 1894). In retrospect, the American Reconceptualization meant an advancement of hermeneutic understanding beyond the European tradition of the humanistic and nationalistic bound notion of the unitary subject with its postmodern fragmentation and explicit introduction of the interplay between language, power and knowledge to curriculum theory.

\section{Travelling Curriculum Discourses: From Herbart to American Psychologized Curriculum}

This intellectual division between hermeneutic Understanding and causal Explanation is already present in Herbart's blueprint for (inherently contradictory?) unified curriculum theory to combine the necessarily free will of the moral agent 
with the causative determination of behavior of the human creature not qualitatively different from other creatures or natural phenomena. Herbart was ambivalent - for good reasons - about the intellectual validity of his contradictory, pre-positivist suggestion and he proposed alternative, hermeneutic model for education and curriculum research that is recognizable today, for instance, in Kelly (2009) and Pinar et al. (1995). Herbart's second, hermeneutic model suggests the relative autonomy of curriculum studies apart from borrowing foreign concepts from other fields: anthropology, philosophy, and psychology. In Herbart's view, educational and curriculum concepts are educational more distinctively, einheimische Begriffe sui generis where education and curriculum should be conceived more autonomously in terms of how we define educative experience which arise from its own practice and its intellectual tradition rather than as conceptual borrowings from alienating and external realms of knowledge (Herbart 1804/1986, in Autio 2006, 105).

Yet, finally - likely due to the scholarly fashions in his day - Herbart's own intellectual ambition was to develop a universal model of a causal "mechanics of mind" in the spirit of deterministic Explanation - eine Mechanik des Geistes - and go down in history as "the Newton of Psychology" - als Newton der Psychologie in die Geschichte einzugehen (Autio 2006, 107).

Later in the Unites States, the short period of American Herbartianism around 1890-1900 was a decisive transition period to organize the assumedly chaotic and confused inner world of the child by organizing "the contents of knowledge in "well-organized"" textbooks and ensure that they are "stored in the mind in well arranged form". The standardization of learning and the child's psyche in the American Herbartianism still took place by reference to inner psychic life that behaviorism was coming to change for the favor of outer behavior. In the 1890s American Herbartianism, "the essence of the position was to produce an identity of outlook among the mass of population; the image of the industrial system demanding uniformity and interchangeability is dominant. The morality and character being sought was a conformity of wills and predictability of behavior; there was no intention of accepting individuality or personal autonomy (Bowen, in Autio 2006, 106 , my emphasis). The intellectual bridge for significant change from inner psychic life to outer behavior between Herbartianism and behaviorism was methodological and conceptual standardization of subjectivity in terms of "learning" as behavior that justified the discard of the assumedly redundant and messy conformity of wills for the assumedly law-like prediction of behavior.

Further, the political pressure by the industrial system for standardization in the late nineteenth century was instrumental to methodologically simplify the theory with displacement of any moral, metaphysical, or existential elements in education theory and remove the Kantian free will of the moral agent, the moral dimension, from the center of the curriculum and education.

As a consequence, there appears a split in the US between "a conformity of wills and predictability of behavior": the "conformity of wills" element remained out of the intellectual and methodological reach of behaviorist agendas. Behaviorism with its intent on the external determination and inductive generalizations of a behavior of an individual predicated on the agenda of positivism creates the powerful norma- 
tivity by the standardization of the subject; individuality and personal autonomy is to conceived not in their genuine idiosyncrasies but in universal, abstract, and collective terms of "learning".

\section{Neoliberal Cause as the Rule of Education}

These early historical, theoretical, and political incentives related particularly to instrumentalism in theoretical terms and industrialization and the economy in practical terms have arguably contributed to the shape of our present crisis of education where we can sense that something went wrong in the turn of the twentieth century in the intellectual design of education when moral and political aspects as goals of education was reduced to psychologized instrumentalism. The children's and peoples' capacity and talents are wasted, neglected or underused particularly by the external assessment obsessions of present education systems what the powerful national and transnational agencies EU, OECD, and the USA advocate. The excessively utilitarian thinking - "economic thought is coterminous with rationality" (Couldry 2011, 28) - sweepingly colonizes with intellectual and moral atrophy historical reminders, present circumstances and future imaginaries of education. Internally, the long tradition of the de-intellectualization of education render it complicit in the neoliberal reduction of the French Enlightenment rationality of liberty, equality and solidarity and its German Bildung equivalent moral, cognitive, aesthetic and practical dimensions of curriculum to instrumentalism of economic thought.

The adoption of the obsolete positivist image of science based on external observation and the ideal of exact measurement in social and education studies can further defy the complexity of education processes by preferring methodological reasons in the definition of educational reality. Neoliberalism policies purposefully but misguidedly advocate the ahistorical, a-theoretical, abstract system-driven and a kind of laboratory images of education research that still reflect the modernist, fundamentalist "quest for certainty"-posture in the numerically forced "evidencebased" interpretations of educational reality.

Paradoxically enough, the period of tumultuous change and instability of financial and economic systems since 2000 that reached the pinnacle in the 2007 financial crisis still going on has not prevented the forces of corporatization from losing their hold on social infrastructure (Goodson 2014, 14). Indeed, "economic thought is coterminous with rationality" (Couldry 2011) and in that all-eggs-in-the-samebasket spirit educational leadership promotes school-as-a-business model and respective business-like "profit projections" of standardized test score results through neoliberal education reforms. Despite the recognized failure of the new economy to create a sustainable new world order, transnational education and curriculum policy hold on the imitation of corporate logic as the educational rule: the "bottom line" in business is structurally and ideologically in congruence with the tested "learning outcomes" in education (Autio 2016, 113). 
These developments lead to the pervasive sense of inversion at many levels, for instance, the move from market economy to becoming market society - "everything is now saleable and available a site of profit making" (Sandel in Goodson 2014, 14). From curriculum and educational leadership perspective, if we are still able to think of education as a prime site for and of democracy, "the inversion of democracy" by neoliberalism would alarmingly mean the repudiation of "a system that was once set up to represent the people against vested power now seems to represent vested power (especially corporate power) against the people. Education policy and leadership can function like a tacit vehicle for these undemocratic ideals to creep into the socialization of future generations in advanced societies as, for instance, the US Through Race to the Top policy program would manifest by the absence of any explicit reference to democracy, education and personality ideals in any broader or holistic sense - except for competitiveness in the economy. The sense of national belonging is still there but subordinated to the assumedly more significant ideals of the market (Autio 2016, 113).

Indeed, "Neoliberalism has become a 'theory of everything' providing a pervasive account of self and identity, knowledge and information, economy and government" (Mirowski in Goodson 2014, 14). In terms of society and governance, "we would seem to be entering a period of 'corporate rule', where all criteria fit the prevailing neo-liberal dogma and where ... even alternative imaginary possibilities are clinically and forcefully expunged (Goodson 2014, 114).

In order to seek historical and theoretical composition and possible alternatives for neoliberalism as the hegemonic ideology of current educational leadership, we cannot evade the impact of Protestantism, especially Calvinism, on present educational landscape. In the context of neoliberalism, reactivation of Calvinist intellectual-theological heritage may illuminate the present in the long historical intertwinement prophetically recorded for first time in Max Weber's The Protestant Ethic and the Spirit of Capitalism (1930/1995). Within Protestantism, Calvinism and Lutheranism radically depart from each other in terms of their respective views on the interrelatedness between individuality and social organization. Both theologies stipulate individual responsibility for God as kernel of human existence with much less influence of the mediating instances of the Holy Scriptures - churchly authorities - that render the core of their "Protest" against Catholic belief and papal institutions. Lutheranism encourages for selfimprovement by advocating literacy, the translation of the Bible and other religious texts to mother tongue that make them available to personal study-motivated by enticing incentives like in the nineteenth and early twentieth century Finland as literacy was a precondition for marriage license. This episodic view on Lutheranism allegorically characterizes the relatively "free", educational nature of Scandinavian interpretation of Lutheranism and how education was connected to the building of the modern state by educationally conditioning the family formation as a basic cell of society. Yet, the mediations between self and society stamped by Luther's doctrine of Two Regiments that subordinate the Earthly to the Heavenly and particularly the Doctrine of Grace give to worldly social organization a kind of positive laissez-faire, less binding but also much more tradi- 
tional and conservative character than strongly interfering measures in Puritan Calvinism to arrange the relationship between the individual and social world (Weber 1995/1930; Autio 2006).

While Lutheranism's attitude toward the world remained to a certain degree indifferent without strictly bounding principles, Calvinism introduced a powerful curriculum to methodize the life of its supporters by interpreting devoted paid work as a sign of religious virtue. "Lutheranism, on account of its doctrine of Grace, lacked a psychological sanction of systematic conduct to compel the methodological rationalization of life. ... The Lutheran faith thus left the spontaneous vitality of impulsive action and naïve emotion more nearly unchanged. The motive to constant self-control and thus to a deliberate regulation of one's own life, which the gloomy doctrine of Calvinism gave, was lacking. ... The simple, sensitive, and peculiarly emotional form of piety, which is the ornament of many of the highest types of Lutherans, finds few parallels in genuine Puritanism (Weber 1995/1930 in Autio 2006, 67).

Calvinism's revolutionary secular impact on the new social order is psychologically based on its diabolically ingenious doctrine of Predestination. The constant uncertainty as to whether one is among the elect (due to the limited but secret number of the elect) creates the basic existential anxiety and the only way of alleviation is to exhibit one's spiritual worthwhileness through work. In the Calvinist view, calling is not a fate, but God's commandment to the individual to work for the divine glory ... with far reaching psychological consequences and, socially, work "became connected with a further development of the providential interpretation of the economic order which had begun in scholasticism (Weber, p. 160). The time horizon and the prime motive of Calvinism was in the future because only the fruits of labor were to reveal to mankind the providential purpose regarding the order of the world. The Calvinist-Puritan stress on the outcomes or the "fruits" of labor constantly challenged the present skills of its practitioners. Thus the human mind and human skills were in constant need of improvement, namely learning and education, in order to work better and better for the glory of God (Autio 2006, 66).

Theological scaffolding provided an early motivation for modern education and, paradoxically, its further, fully-fledged secularization and, most significantly, for the idea and concept of progress. These developments related to secularization and the pre-pragmatic notions by Francis Bacon (1561-1626): "Truth and Utility are ... the very same things" (Autio 2006, 20) can be read as a historical-theoretical prelude to our full-blown instrumentalist, neoliberal concepts of education, curriculum and leadership where the concept of "truth" as current anachronism is absorbed and removed by the guiding principle of education policies of today: high outputs at the lowest possible costs.

Initial theological incentives in educational thinking are buried in the tradition of Anglophone, especially in the Anglo-American Curriculum. The historical forging of American education has not of course any single origin, it is a long-term, com- 
plex process whose principles are assembled and connected to a myriad of different patterns that include religious, political, philosophical, social, and cultural discourses.

From the current perspective, the Bildung tradition is hardly present in any of present national educational and curriculum discourses, policies and practices. The only exception still may be Finland when the rest of the Scandinavian front (Denmark, Norway, Sweden) is fragmented to more or less neoliberal blocks with Anglophone accountability, standardization and privatization policy and leadership drivers. Finland's case is interesting in terms of the divide between psychologized Curriculum and Bildung that has not captured much attention in the PISA reception but what is highly significant in the current context of educational leadership. In a matter of fact, we can claim that the good Finnish results in PISA paradoxically and at least temporarily saved Finland from the Anglophone and OECD driven GERM, "virus that is killing education" (Sahlberg 2011). The success in the first PISA round in 2001 was a huge surprise in Finland; it was an unintended consequence and side product of the broad-based, holistic national curriculum, teachers' professional freedom and the democratic Finnish concept of comprehensive school (peruskoulu). The peruskoulu was constantly attacked since its creation from 1970s by the political right and the leaders of business sector but this critique was silenced overnight when the first PISA results were issued in 2001 (Saari et al. 2014). Without PISA surprise, Finland would most probably be engaged in transnational neoliberal policy drivers accountability, standardization and privatization. Characteristic to the Finnish peruskoulu is the academically qualified teachers, (master level requirement at all levels), implied in professional autonomy, freedom and high trust in teachers, the absence of external assessments and tests (practically all tests are teacherdriven), the not-stigmatizing support in cases of social and educational challenges, etc. Teaching is related to holistic education, in strict contrast with countries where teaching basically means teaching to the externally mandated tests. The decisive element in Finnish comprehensive school ideology is the interpretation of quality as equality; quality as equal educational opportunity regardless of social, economic or ethnic background. Again, that Finnish policy principle is in strict contrast with the Coleman report (1966, in Pinar 2006, 123-124) and its neoliberal offspring the NCLB and TRTT policy programs where educational (e)quality is linked to test scores by quasi-causal psychological argumentation used to advocate the intellectually dishonest and simplified conception of teaching as a "cause" and learning as an "effect". "Only if students from differing groups scored roughly the same scores, Coleman insisted, could we conclude there was equal educational opportunity" (Pinar 2006, 124).

Comparable to Sputnik shock in the 1950s USA, Germany experienced a PISA shock in 2001 that created a debate about the conflation between the concept of knowledge and competences, skills and performances. Apart from the shock of the PISA results as such, in the aftermath the debate in Germany created a conceptual shock that is very significant from the perspective of curriculum theory and educational leadership. To the proponents of traditional Bildung concept a shocking move 
by some German PISA experts was to suggest the concept of competence as a new Bildung concept: "Kompetenz - ein neuer Bildungsbegriff".

It is important to note, ..., that the merging of competencies and Bildung is not solely an act by historically blind empiricists ... Heinz-Elmar Tenorth, a genuine historian of education, did the very same thing: "Bildung and literacy, basic skills and modes of handling higher culture do not depict disjunctive classes of knowledge and behavioral patterns but specific developments of a single and identical dimension of human practice." (Tröhler 2011, 196)

Here, in an unexpected context of Bildung, we witness a single instance of neoliberalism as "a theory of everything", a discourse on education, knowledge and subjectivity, all conflated together as an image of the human subject reduced to a sheer aggregate of competences.

The example is a generalizable index of the current state of Bildung in its homeland Germany where it is increasingly colonized in the aftermath of the PISA shock by the instrumentalism of Anglo-American psychologized Curriculum.

PISA has led to the growing importance of principles such as outcome control, competence orientation and external assessment. The post-PISA academic discourse in Germany can be characterised by the re-orientation of educational studies towards a greater emphasis on the empirical research of pedagogic practice (empirische Unterrichtsforschung). (Ertl 2006, 619)

The reaction in Germany to PISA to get intellectually allied with transnational, narrow and detrimental psychologized agendas is just the opposite what is the case in Finland. PISA, paradoxically, has increased educational self-esteem to maintain and develop education, curriculum and leadership policies that preserve curriculum breadth and depth, academic teacher education with guided practice, teachers' untouchable professional autonomy and freedom and students' increasing involvement in school decisions that would affect them. In the 2016 new national curriculum reform students are invited from first grade on to actively participate with teachers in the assessment not only of learning and study process but also students' overall judgment over the quality of life at school. Despite the transnational terminological pressures to replace knowledge and education in favor of neoliberal and psychologized vocabulary of competencies, skills and performances, the atmosphere in Finnish comprehensive school still seems to adhering to the Deweyan conception of the school as a specific institution, confirming its status as a prime site of democracy: education is of and for democracy, strictly contrasting with antidemocratic, neoliberal drivers of external accountability, standardization and accountability based on rudimentary "evidence-based" scientism. 


\title{
Toward Genuine Theorization and Reactivation of the Past in Education: The Educational Landscape of Internationalization Between West and East (China) as a Reaction to Neoliberal Globalization
}

The German post-PISA case with all conceptual confusions like there were attempt to marry fire and water is to be conceived as an index of lack of theorization and lost sense of intellectual history of education and curriculum. Particularly in the Anglophone empiricist world, there is perceivable a long empiricist and pragmatist tradition where method is replacing comprehensive theorization in research and teacher education curricula. Not directly related to the aftermath of PISA shock, Ewald Terhart $(2003,25-26)$ registers the instigation of education paradigm shift in Germany toward ahistorical and a-theoretical Anglophone empiricism and psychologism:

\begin{abstract}
In Germany, it has become quiet around general didactics. The controversies of the late 1960s and early 1970s have died down; the theoretical situation has been basically stable for decades. ... this is surprising because one might perhaps expect, given the widespread talk about the crisis in instruction, in school, and the teaching profession, that the wheat of didactics would bloom on a theoretical level. Just the opposite is the case! In general didactics, there has been no theoretical discussion worth speaking of for around 2 decades ... genuine theoretical discussion has been largely replaced by the development and defense of certain teaching methods on a more practical level.
\end{abstract}

Increased awareness of the excessive instrumentalism and its detrimental effects on education in the United States that would urge genuine theoretical and historical reconsideration was embodying already in the 1970s in the scholarship of William Pinar. Reconsideration that was essentially drawing on critique of educational psychology, the Tyler Rationale as its icon, lead to re-conceptualizing of the ahistorical, psychologized concept of curriculum by behaviorism and cognitivism. The Reconceptualization Movement, "as an intellectual breakthrough" in the American context, materialized as a monumental magnum opus of American curriculum theory and history Understanding Curriculum coauthored by William Pinar et al. (1995), is sharing some intellectual affinities with German and north European Bildung but also critical reappraising and 'post-modernizing' some of Bildung tenets.

In terms of theory of science, the positivism of educational psychology as a vehicle of the psychologized Curriculum identify itself with the ideals of causal explanation, in turn, Bildung and the Reconceptualization share the common affiliation with hermeneutic concept of science with respective ideals of understanding of meanings, intentions and the interplay between the whole and the parts. Hermeneutics is a reaction to the methodological monism of positivism (Wright von 1971) and this reaction is specified respectively, in modernist terms, in Bildung and, in postmodernist sense, in Reconceptualization theories and concept. The American Reconceptualization meant a decisive advancement of hermeneutic understanding beyond the European tradition of the humanistic and nationalistic bound notion of 
the unitary subject with its postmodern fragmentation and explicit introduction of a interplay between language, power and knowledge to curriculum theory.

The hermeneutic critique directed to both Anglo-American abstract, instrumental, method-driven psychology and Bildung concepts of the unitary humanistic, nationally bound subject has transformed the educationally vital discourse on the subject from male dominated WASP discourse exemplified in the Tyler Rationale, the English gentleman ideal of education and the elitist, erudite, nationalistic male individual of the Bildung ideal toward gender-, culture- and internationally sensitive discourses on subjectivity. These intellectual shifts have radically transformed the landscape of education and curriculum through more nuanced dynamics of the subject facilitated by richer palettes of research methodology than is the case of routinized, unimaginative empiricism of surveys in current educational policies and leadership. For instance, the introduction of (auto)biographical research methods is essentially increasing knowledge and understanding what it is be a human being, teacher and student in the present world in more authentic, practical, and comprehensive ways than the mechanistic politics of behaviorist and cognitivist psychologies have provided or could in principle provide within their limited epistemic and methodological boundaries.

The interest to take individuality more comprehensively than traditional educational psychology by employing new methodologies implied in the intellectual legacies of Bildung and Reconceptualization has vital political implications. By scrutinizing internal and external circumstances of an individual, current curriculum theory/studies would reconsider and challenge the preconditions of democracy by amplifying and articulating more explicitly individual potentialities through narrative and biographical approaches. The urge to rethink individuality, subjectivity, agency, or self would denote a theoretical articulation of the current situation where individualization - biographical differences - has become "a structural characteristics of highly differentiated societies" (Beck and Beck-Gernsheim 2002, xxi; Autio 2006, 160).

The intensified individualism is tied to globalization, both of them marking the constitutive features of postmodernity, or in Ulrich Beck's terms, 'the second modernity'. Globalization has by the outsourcing of the functions of "the first modernity" effected a radical shift in the relationships between individuals and institutions (Autio 2006, 160). The neoliberal measures of external accountability, standardization and privatization are educational symptoms of globalization to which curriculum theory is reacting by inter-nationalization to effect the sense of historicity, locality, nuance, and fragmentation countering uniform standards of transnational reform and leadership mindset.

As Ulrich Beck and Elizabeth Beck-Gernsheim (Autio 2006, 161) point out, the move toward complexity has meant "a de-normalization of roles"; "the roles of the first modernity depended very much on what Kant called determinate judgment; on prescription, on determinate rules". 
Now, the individual must be much more the rule finder her/himself. Determinate judgment is replaced by "reflective judgment". Reflective judgment is not reflection because there is no universal to subsume the particular. In reflective judgment the individual must find the rule. Reflective judgment is always a question of uncertainty, of risk, but it always leaves the door open much more to innovation. (Lash, in Beck and Beck-Gernsheim, cited in Autio 2006, 162)

Mutatis mutandis, Scott Lash's description of a capable individual in the current world of "second modernity" or postmodernity could be a description what pedagogic practice has always been, "good teacherhood"(Goodson 2014) or "teaching as a reflective practice" (Westbury et al. 2000), in the spirit of Bildung - in sharp disagreement with pseudo-causal "evidence-based" and assessment-driven neoliberal education and leadership policies where - with glaring theoretical simplicity but political purposefulness - teaching is imagined as a "cause" and learning as an "effect".

the countries that have pursued neo-liberal reforms in the fastest and deepest manner, such as England, perform very poorly in educational standards. Meanwhile, those that have defended a social democratic vision and have explicitly valued professional autonomy, such as Finland, have produced top-rate educational standards. It would seem time to seriously scrutinise the neo-liberal orthodoxy in the field of education. (Goodson 2014, 43-44)

As "the curriculum provides a prism, a litmus test, through which to see and test societal health and character" (Goodson 2014, 14), likewise the positioning of the teacher within the curriculum is the litmus test of educational leadership. In terms of curriculum theory, there are basically two already described variants: psychologized Curriculum as managerial, transnational kernel of educational leadership or curriculum receptions motivated and reactivated by Bildung and Reconceptualization that stipulate the teacher as an academically educated, free professional rather than "the agent or the conduit of the system":

The managerial perspective of curriculum [as the embodiment of the dominant psychologized curriculum theory, my add.], teachers are always the invisible agents of the system, seen as "animated" and directed by the system, and not sources of animation for the system. This starting point leads to a view that existing teachers are a (if not the) major break on the innovation, change, and reform that the schools seem to require. ... it is this view of the teacher as a cipher for the formal curriculum that represents perhaps the major source of internal tension within contemporary, ... [psychologized, my add.] curriculum theory and practice. ... it is their respective views of the teacher, and the role the teacher is given within their theoretical and institutional systems, that represents the most dramatic difference in viewpoint between Didaktik and [psychologized, my add.] curriculum theory. (Westbury et al. 2000, 21)

The wider perception that there are theoretical alternatives and the recognition of respective impact of adopted curriculum theory on the work and professional identity of teachers is an international counter reaction to measures of neoliberal education policy and leadership. Yet, the reactions are uneven and vary paradoxically even in countries traditionally affiliated with Bildung theories like in post-Pisa Germany and in Sweden, Finland as an obvious exception. 
In the US, there are interesting efforts to overcome the Westburyan picture of the (American) teacher as a cipher for impersonal learning theories and the formal curriculum by the introduction of curriculum design and practice informed by Reconceptualized, autobiographical theories into the discourses of being a teacher and pedagogic artistry (Henderson et al. 2015) as guiding beacons for educational leadership. A kindred perception by Ivor Goodson $(2014,16)$ importantly extends the being a teacher and pedagogic artistry to education reform. The acid test here is the sustainability of change. The key lacuna in externally mandated change is the link to teachers' professional beliefs and teachers' own personal missions. New research findings in education reform patently show that personal and professional commitment must exist at the heart of any new changes or reforms. "Not only is it neutrally absent, it is in fact positively absent in the sense that there is a mixture of profound indifference and active hostility to so many changes and reforms" (ibid.).

One of the most interesting process in this sense of post-psychologism and poststandardization is taking place in China when the huge country is liberalizing and modernizing its education systems and developing curriculum theory and practice, internationally receptive and well-informed, still adjusted to the national, regional and local traditions, present circumstances and future imaginaries. China's education and curriculum strategy seems to be a hybrid one: the international comparisons like the PISA, TIMSS etc. keeps China, obviously for superpower reasons and its long tradition of externally mandated exams, alert to be competitive in the OECD and other organizations' tests and "racetracks". Simultaneously and apart from the standardizing global competition, China seems to make efforts to struggle against that 'global virus', Global Education Reform Movement, by seeking sources to rephrase and hybridize its "wisdom traditions" of Buddhism, Confucianism and Taoism together with Western theoretical novelties, like poststructuralism and postmodernism in curriculum theory.

China's modernization and its impact will not just be economic but cultural too. China's modernization may suggest in a longer run the way out - in a spirit of the Hegelian dialectic - both from the current fundamental and structural crises of Capitalism and obsolete and rigid Socialism. "The reason for China's transformation (...) has been the way it has succeeded in combining what it has learnt from the West, and also its East Asian neighbors, with its own history and culture, whereby tapping and releasing its native sources of dynamism. We have moved from the era of either/or to one characterized by hybridity" (Jacques 2012, 562).

China's hybrid modernization may signal a cultural feedback to Western notions of modernity and a future of an emergence of contested modernities. If we think about the age of the Enlightenment as the huge educational project, China's modernization and its global cultural impact would imply a need to reconsidering the European Bildung/Didaktik as well as Anglo-American Curriculum as two (Western) master narratives of curriculum theory. In the research project lead by William Pinar (2014): Curriculum Studies in China: Intellectual Histories, Present Circumstances, the chapters by Chinese curriculum scholars bear witness to the 
decisive turn away from the globally spread US reform model of accountability, standardization and teaching to the test - all based on superficial notions of human psyche, human activity and on absurdly narrow educational rationality. Intellectually and culturally profiled, emerging Chinese curriculum theory and practice seem to be affiliating with the North American post-reconceptualization Currere and older European Bildung thought reactivated, localized and hybridized by Chinese wisdom traditions. Chinese distinctive emphases on curriculum theory (Zhang 2014a) may as such work like antidote to schematic, routinized instrumentality and "teaching-by-numbers" mentality in education policy, leadership, and practice in most of Western countries. In Zhang's enthusiastic precondition for curriculum theory is echoed the hybrid resonances with the Eastern wisdom traditions and Western reappraisals of curriculum theory: "No Freedom, No Curriculum!" (Zhang 2014a).

Against the atrophy of economic and political liberalism and democracy to neoliberalism and neo-conservatism, educationally manifested in the totalitarian accountability and standardization, the Chinese opening might shed new light into the world of education by its contested modernity like the postmodern scholarship of Zhang Wenjun (2014b) signals in the Chinese context. Also the ongoing school reforms in China resonate in the reactivated Bildung-Currere spirit the marriage between agency and freedom, so vital to successful education system through the recognition of the significance of the broad-based teacher education curriculum and the positioning of the teacher beyond the sheer conduit of the system. Yuting Chen (2014) speaks powerfully against the grain of Western top-down reforms controlled by standardization and accountability by alternatively predicating on the necessary role of every single school as the "Reform Subject" when schools' role is transformed from the target of implementation, standardization and accountability, "From Follower to Creator", to the active agent of a reform.

China's monumental "liberalizing and modernizing education reforms" is informative in their attempts to overcome the intellectual limitations and exhaustion of presentist empirical social and educational sciences as resources for education reforms. Instead of the modernist four boxes model and division of labor in educational sciences - history, philosophy, psychology and sociology of education - academic study of education and teacher education in China is reorganized as Curriculum Studies.

Curriculum Studies, comprising curriculum theory, curriculum history and curriculum design create the intellectual center of educational sciences and teacher education curricula (Autio 2014) and provide an academic framework and intellectual support for education and curriculum reforms: curriculum becomes an organizational and intellectual center of education. While viewing curriculum as an intellectual and organizational centerpiece of education, Curriculum Studies in China can be seen as a reactivation of the double meaning of Bildung /Didaktik discourse in German-speaking and North European traditions where they can refer to both theory and practice. While reform in China is focused on questions of prac- 
tice, it is not exclusively organizational, "as quite an unproblematic syllabus or content to be taught/transmitted/delivered/tested" but strives "towards more intellectual, more complicated understanding of curriculum" (Pinar 2014, 182). And: "while definitely organizational, the current curriculum reform is profoundly political and intellectual, informed, ..., by culture and history" (Pinar 2014, 21).

\begin{abstract}
Rather than degrading public education, as US politicians have done since Sputnik, in China the Ministry of Education encourages reform through consultation with experts, including contributors to this volume. Rather than imposing a simplistic model of reform, as in the United States, in China the ministry demands complexity and local innovation, not in the service of standardization but to promote organizational diversity and studentcenteredness. In their intellectual courage, their ethical conviction, and their cosmopolitan incorporation of concepts, ancient and contemporary (East and West), curriculum researchers in China demonstrate that the future of education is not inevitably the tragic tale it too often is in the West today. (ibid., 1)
\end{abstract}

The lessons from internationally informed curriculum theory, one of the most vibrant fields of educational study, persuade us to believe that the world of education can be named differently. The fatal discard of moral, historical and democratic elements as vital preconditions for educational discourse by methodologies of positivism and presentist pragmatism has contributed to the neoliberal simulation of education. Separated divisions of labor in education research (history, philosophy, psychology, sociology) have been unable to provide a view comprehensive enough on the contested discourses of education so vital for sound educational leadership. Genuinely international curriculum theory could be a credible source for theoretical and practical uses of leadership by introducing educational concepts more sui generis which have hovered in the minds of prominent curriculum scholars throughout modern times from Herbart's einheimische Begriffe to Kelly's (2004) and Pinar's et al. (1995) views on curriculum as a study of its own right.

\title{
References
}

Apple, M. (2006). Educating the right way, markets, standards, God and inequality. New York: Routledge.

Autio, T. (2006). Subjectivity, curriculum and society. Beyond and between German Didaktik and Anglo-American Curriculum. New York: Routledge.

Autio, T. (2014). The internationalization of curriculum research. In W. F. Pinar (Ed.), International handbook of curriculum research (2nd ed.). New York: Routledge.

Autio, T. (2016). Contested educational spaces: Some tentative considerations inspired by curriculum theory and history. IJHE Bildungsgeschichte: International Journal for the Historiography of Education, Heft 1-2016.

Beck, U. \& Beck-Gernsheim, E. (2002). Individualization: Institutional individualism and its social and political consequences. London: Sage.

Blass, J. (1978). Modelle pädagogischer Theoriebildung. Band I. Von Kant bis Marx. Stuttgart: Verlag W. Kohlhammer.

Couldry, N. (2011). Why voice matters? Culture and politics after neoliberalism. London: Sage Publications. 
Crook, S., Pakulski, J., \& Waters, M. (1992). Postmodernization: Change in advanced society. London: Sage.

Dilthey, W. (1894). Ideen über eine beschreibende und zergliedernde Psychologie. In: W. Dilthey, Gesammelte Schriften, Bd. V. Stuttgart/Göttingen: B. G. Teubner Verlagsgesellschaft/ Vandenhoeck \& Ruprecht.

Doll, W. E. (1993). Post-modern perspective on curriculum. New York: Teachers College Press.

Ertl, H. (2006). Educational standards and the changing discourse on education: The reception and consequences of the PISA study in Germany. Oxford Review of Education, 32(5), 619-634.

Goodson, I. (2014). Curriculum, personal narrative and the social future. New York: Routledge.

Habermas, J. (1984). The theory of communicative action (Vol. 1). Boston: Beacon Press.

Hargreaves, A., Lieberman, A., Fullan, M., \& Hopkins, D. (Eds.). (2009). Second International handbook of educational change. Dordrecht: Springer.

Henderson, J., et al. (2015). Reconceptualizing curriculum development. New York: Routledge.

Jacques, M. (2012). When China rules the world: The end of the Western world and the birth of a new global order. [Greatly updated and expanded]. London: Penguin.

Kant, I. (1984). Kritik der praktischen Vernunft. Stuttgart: Philipp Reclam.

Kant, I. (1991). Education. Ann Arbor: University of Michigan Press.

Kelly, A. V. (2004). The curriculum: Theory and practice (5th ed.). London: Sage.

Kelly, A. V. (2009). The curriculum: Theory and practice (6th ed.). London: Sage.

Klafki, W. (1991). Neue Studien zur Bildungstheorie und Didaktik. Weinheim: Beltz Verlag.

Lather, P. (2010). Engaging science policy: From the side of the messy. New York: Peter Lang.

Pinar, W. F. (2006). The synoptic text today and other essays. New York: Peter Lang.

Pinar, W. F. (2011). The character of curriculum studies: Bildung, currere, and the recurring question of the subject. New York: Palgrave Macmillan.

Pinar, W. F. (2013). Curriculum studies in the United States: Present circumstances, intellectual histories. New York: Palgrave Macmillan.

Pinar, W. F. (2014). Curriculum studies in China: Present circumstances, intellectual histories. New York: Palgrave Macmillan.

Pinar, W., Reynolds, W., Slattery, P., \& Taubman, P. (1995). Understanding curriculum. Historical and contemporary discourses. New York: Routledge.

Ravitch, D. (2010, March 9). Why I changed my mind about school reform. Federal testing has narrowed education and charter schools have failed to live up to their promise. The Wall Street Journal.

Saari, A., Salmela, S., \& Vilkkila, J. (2014). Governing autonomy. Subjectivity, freedom, and knowledge in Finnish curriculum discourse. In W. F. Pinar (Ed.), International handbook of curriculum research (2nd ed., pp. 183-200). New York: Routledge.

Sahlberg, P. (2011). Finnish lessons: What can the world learn from educational change in Finland. New York: Teachers College Press.

Terhart, E. (2003). Constructivism and teaching: A new paradigm in general didactics. Journal of Curriculum Studies, 35(1), 25-44.

Tröhler, D. (2011). Languages of education. New York: Routledge.

Tröhler, D. (2013). Pestalozzi and the Educationalization of the World. Netherlands: Springer.

Tyler, R. (1949). Basic principles of curriculum and instruction. Chicago: Chicago University Press.

Weber, M. (1978). In G. Roth \& C. Wittich (Eds.), Economy and society. An outline of interpretive sociology (Two Vols). Berkeley: University of California Press.

Weber, M. (1995/1930). The protestant ethic and the spirit of capitalism. London: Routledge.

Westbury, I., Hopmann, S., \& Riquarts, K. (2000). Teaching as a reflective practice: The German Didaktik tradition. Mahwah: Lawrence Erlbaum.

Wright von, G. H. (1971). Explanation and understanding. New York: Cornell University press.

Yuting, C. (2014). From follower to creator: School as reform subject. In W. F. Pinar (Ed.), Curriculum studies in China: Intellectual histories, present circumstances. New York: Palgrave Macmillan. 
Zhang, H. (2014a). Curriculum studies and curriculum reform in China: 1922-2012. In W. F. Pinar (Ed.), Curriculum studies in China: Intellectual histories, present circumstances. New York: Palgrave Macmillan.

Zhang, W. (2014b). Growing with Postmodernism. In W. F. Pinar (Ed.), Curriculum studies in China: Intellectual histories, present circumstances. New York: Palgrave Macmillan.

Open Access This chapter is licensed under the terms of the Creative Commons Attribution 4.0 International License (http://creativecommons.org/licenses/by/4.0/), which permits use, sharing, adaptation, distribution and reproduction in any medium or format, as long as you give appropriate credit to the original author(s) and the source, provide a link to the Creative Commons license and indicate if changes were made.

The images or other third party material in this chapter are included in the chapter's Creative Commons license, unless indicated otherwise in a credit line to the material. If material is not included in the chapter's Creative Commons license and your intended use is not permitted by statutory regulation or exceeds the permitted use, you will need to obtain permission directly from the copyright holder. 